\title{
Spatial Differentiation of Ascomycetes of the Malaisary Ridge (Kazakhstan)
}

\begin{abstract}
Rakhimova $\mathrm{YV}^{*}$, Yermekova BD, Kyzmetova LA, Jetigenova UK and Assylbek AM

Laboratory of Mycology and Algology, Institute of Botany and Phytointroduction, Kazakhstan
\end{abstract}

*Corresponding author: Yelena Rakhimova, Laboratory of Mycology and Algology, Institute of Botany and Phytointroduction, Timiryazev Str. 36D, 050040, Almaty, Kazakhstan, Tel:

\section{Research Article}

Volume 3 Issue 1

Received Date: January 20, 2020

Published Date: February 21, 2020

DOI: $10.23880 /$ oajmms-16000118

8-777-346-10-40; Email: evrakhimova1961@yandex.ru

\section{Abstract}

Malaisary Mountains are located on the territory of Kazakhstan (southeastern regions) $120 \mathrm{~km}$ from the Almaty city. Mycobiota of the Malaisary ridge has 99 species belonging to ascomycetes. Ascomycete's fungi are represented by 11 orders from 3 classes. The highest number of orders (5) is characteristic of the class Dothideomycetes. The largest genera are Mycosphaerella (7 species), Pleospora (7 species) and Ramularia (5 species). The most other genera contain 1-2 species. The class of Leotiomycetes is represented by 2 orders, 2 families with 8 genera. The largest genera are Golovinomyces ( 6 species), Erysiphe (6 species) and Podosphaera (5 species), related to order Erysiphales. The greatest number of species of ascomycetes is noted in the steppe belt of the Malaisary ridge: on the northern macroslope 35 species from 23 genera, on the southern macroslope 46 species from 26 genera. A large number of species on the southern slope is registered due to the fact that it is rocky and steep with deep gorges. In the steppe belt of the Malaisary ridge only 12 species of ascomycetes are common between the northern and southern macroslopes, and the vast majority of them belong to powdery mildew fungi ( 8 species). The northern macro slope is characterized by a diversity of representatives of the genera Mycosphaerella and Selenophoma, while the southern macroscope-by representatives of the genus Ramularia.

Keywords: Ascomycete; Fungus; Malaisary Ridge; Powdery Mildew; Species

\section{Introduction}

The small flattened mountains of Malaisary are located on the territory of Kazakhstan $120 \mathrm{~km}$ from the Almaty city and are the most western spur of the Dzungarian Alatau. The length of the ridge is approximately $80 \mathrm{~km}$, the width$10 \mathrm{~km}$ and the absolute height-not more than $1500 \mathrm{~m}$ above sea level. In the west, the Malaisary mountains abut the Ili river, in the southeast they pass into the Chulak mountains (Chulaktau, Sholak), to the south, the low-mountainous relief of Malaisary smoothly passes into the inclined plains of the Karoy plateau (860-920m above sea level).
The relief of the Malaisary Mountains is hilly, the north side (macroslope) is gentler, and the south side (macroslope) is rocky with deep gorges. Some spurs stand out from the main ridge: Kulanbasy (Kumbasy), Arkharly and Tasmurun mountains. The river network is extremely poorly developed. All rivers dry up, turning into dry channels or stony watercourse. There are several springs and artesian wells that are used for the needs of the population. The climate in the described territory is sharply continental with significant amplitude of temperature fluctuations. The average annual temperature is about $+4.5^{\circ} \mathrm{C}$. The coldest month is January with an average temperature of $-7^{\circ} \mathrm{C}$, the hottest month is 


\section{Open Access Journal of Mycology \& Mycological Sciences}

July with an average temperature of $+30^{\circ} \mathrm{C}$. The snow cover is shallow $(10-20 \mathrm{~cm})$ and unstable, lasts for 50 days. The total precipitation is about $150 \mathrm{~mm}$ per year. Almost 60 days a year drought lasts here [1].

Desert climate affects the vegetation of the Malaisary ridge. Altitudinal belts begin with desert foothills, which are replaced by semi-desert and steppe zones. There is no forest belt, only along the gorges and northern slopes there are shrubs-hens, wild cherries, spirea and rose hips. Despite the scarcity of mountain vegetation, a large number of endemic and relict species are found in the flora.

From a mycological point of view, the Malaisary ridge has been practically unexplored for a long time. Some samples were collected through the ridge in 2010, 2012, 2013. During the implementation of the project "The current state of species diversity of mycobiota and algoflora in the desert lowlands of the southeast of Kazakhstan and their rational use" (2014-2017), the northern and southern macroslopes of the Malaisary Ridge, Arkharly and Kulanbasy mountains were examined by the staff of the Laboratory of Mycology and Algology of the Institute of Botany and Phytointroduction.

The Malaisary ridge is characterized with the DzhungarNorthern-Tyanshan type of zonation. Two zones are clearly distinguished: foothill deserts (with a predominance of wormwood) and steppes (with the dominance of turfgrains). Vertically the length of each zone is approximately 300400m: piedmont deserts-600-900m, steppes-900-1300m. Mesophytic shrubs (meadowsweet, hens, and dogrose) are characteristic of the northern slopes and hollows. Ephemers and ephemeroids play a significant role [2].

Research area belongs to the desert lowlands, which are distinguished by a variegated and diverse vegetation cover and a significant representation of rare plants listed in the Red Book of Kazakhstan [3]. Poor knowledge of the mycobiota of the desert lowlands served as the basis for their mycological examination. The purpose of this article is to study the spatial differentiation of the biota of ascomycetes of the Malaisary ridge.

\section{Materials and Methods}

The study was conducted in the Malaisary ridge (Figures $1 \& 2$ ) (southeastern regions of Kazakhstan) for several years (2004, 2005, 2013-2017).

Different parts of plants with symptoms of fungal diseases and various substrates with visible fungal development were collected during field trips. A Canon 600E camera was used for photographing of fungi.
For light microscopy, small fragments of samples were stripped off the substrates, placed in a drop of distilled water on a microscope slide without any staining [4], examined and photographed using a photomicroscope Polyvar with Nomarski interference contrast optics. Measurements of different fungal structure were made. Specimens were identified with the literature on ascomycetes [5-15].

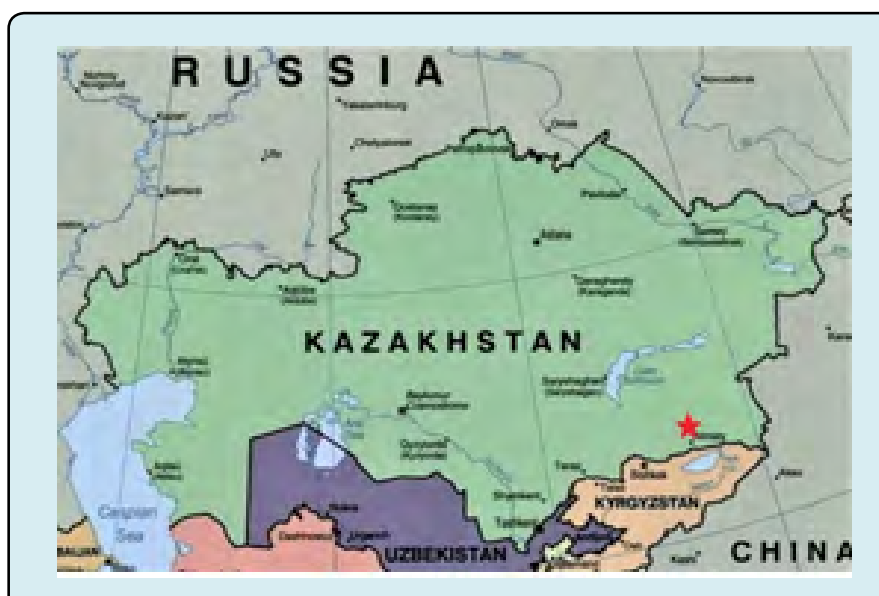

Figure 1: Map of Kazakhstan showing the locality of Malaisary ridge (asterix).

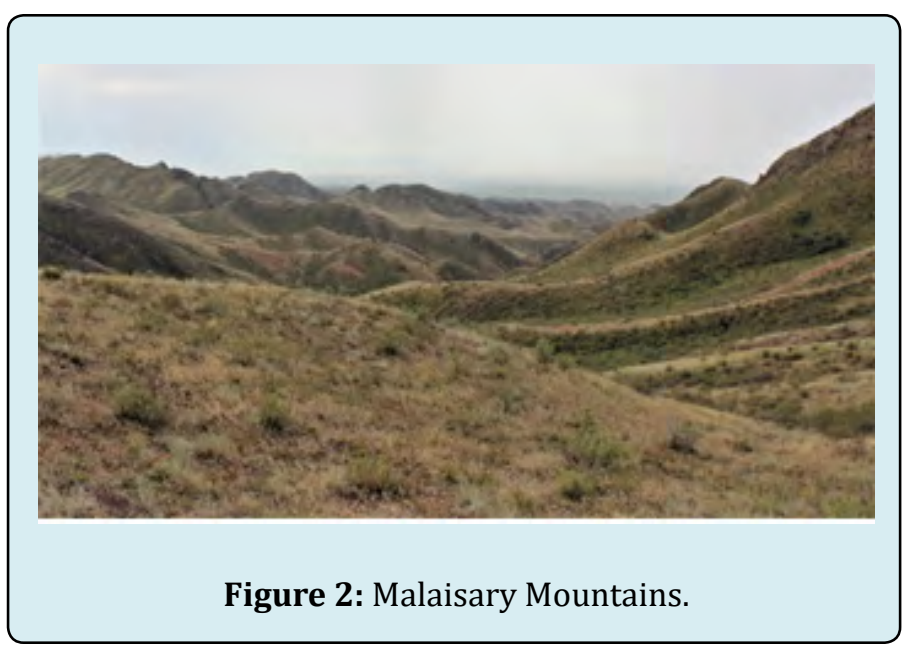

Dried specimens are stored in the herbarium of the Institute of Botany and Phytointroduction, Almaty, Kazakhstan (AA).

The systematics of the taxa is in accordance with Ainsworth and Bisby's dictionary of the fungi and they are listed in alphabetical order [16]. The names of the host plants are given in accordance with the on-line identifier of plants [17], the names of fungal taxa -in accordance with the Index Fungorum database [18]. 


\section{Open Access Journal of Mycology \& Mycological Sciences}

\section{Results}

Recently, the mycobiota of the Malaisary ridge has 99 species belonging to ascomycetes (Table 1). Ascomycete's fungi are represented by 11 orders from 3 classes. Three genera (Fumago, Hormiscium, and Torula) have an unclear systematic position. The highest number of orders is characteristic of the class Dothideomycetes. The largest genera are Mycosphaerella (7 species), Pleospora (7 species) and Ramularia (5 species). The most other genera contain 1-2 species. Two genera of Dothideomycetes (Camarosporium and Placosphaeria) have an unclear systematic position.

\begin{tabular}{|c|c|c|c|c|}
\hline Class & Order & Family & Genus & Number of Species \\
\hline & \multirow{3}{*}{\multicolumn{2}{|c|}{ Insertae sedis }} & Fumago & 1 \\
\hline & & & Hormiscium & 1 \\
\hline & & & Torula & 2 \\
\hline \multirow{25}{*}{ Dothideomycetes } & \multirow{2}{*}{ Botryosphaeriales } & \multirow{2}{*}{ Botryosphaeriaceae } & Diplodia & 1 \\
\hline & & & Microdiplodia & 1 \\
\hline & \multirow{4}{*}{ Capnodiales } & Davidiellaceae & Cladosporium & 3 \\
\hline & & \multirow{3}{*}{ Mycosphaerellaceae } & Mycosphaerella & 7 \\
\hline & & & Ramularia & 5 \\
\hline & & & Septoria & 4 \\
\hline & \multirow{3}{*}{ Dothideales } & \multirow{3}{*}{ Dothioraceae } & Discosphaerina & 1 \\
\hline & & & Kabatia & 1 \\
\hline & & & Selenophoma & 5 \\
\hline & Hysteriales & Hysteriaceae & Graphyllium & 1 \\
\hline & \multirow{13}{*}{ Pleosporales } & Cucurbitariaceae & Cucurbitaria & 2 \\
\hline & & Didymellaceae & Phoma & 2 \\
\hline & & Leptosphaeriaceae & Leptosphaeria & 1 \\
\hline & & Lophiostomataceae & Lophiostoma & 2 \\
\hline & & Melanommataceae & Ohleria & 1 \\
\hline & & \multirow{3}{*}{ Phaeosphaeriaceae } & Phaeosphaeria & 2 \\
\hline & & & Sphaerellopsis & 1 \\
\hline & & & Ampelomyces & 1 \\
\hline & & Pleomassariaceae & Pleomassaria & 1 \\
\hline & & \multirow{4}{*}{ Pleosporaceae } & Alternaria & 2 \\
\hline & & & Macrosporium & 1 \\
\hline & & & Pleospora & 7 \\
\hline & & & Stemphylium & 2 \\
\hline & \multirow{2}{*}{\multicolumn{2}{|c|}{ Insertae sedis }} & Camarosporium & 2 \\
\hline & & & Placosphaeria & 1 \\
\hline \multirow{8}{*}{ Leotiomycetes } & \multirow{6}{*}{ Erysiphales } & \multirow{6}{*}{ Erysiphaceae } & Blumeria & 1 \\
\hline & & & Erysiphe & 6 \\
\hline & & & Golovinomyces & 6 \\
\hline & & & Leveillula & 1 \\
\hline & & & Neoerysiphe & 2 \\
\hline & & & Podosphaera & 5 \\
\hline & Helotiales & Dermateaceae & Pseudopeziza & 2 \\
\hline & \multicolumn{2}{|c|}{ Insertae sedis } & Cylindrosporium & 2 \\
\hline
\end{tabular}




\section{Open Access Journal of Mycology \& Mycological Sciences}

\begin{tabular}{|c|c|c|c|c|}
\hline \multirow{3}{*}{ Pezizomycetes } & \multicolumn{2}{|c|}{ Insertae sedis } & Pseudodichomera & 1 \\
\cline { 3 - 5 } & & Schwarzmannia & 1 \\
\hline \multirow{4}{*}{ Sordariomycetes } & \multirow{2}{*}{ Diaporthales } & Pseudovalsaceae & Coryneum & 1 \\
\cline { 2 - 5 } & Hypocreales & Clavicipitaceae & Leucostoma & 1 \\
\cline { 2 - 5 } & Phyllachorales & Phyllachoraceae & Polystigma & 1 \\
\cline { 2 - 5 } & \multirow{2}{*}{ Xylariales } & \multirow{2}{*}{ Xylariaceae } & Poronia & 1 \\
\cline { 2 - 5 } & \multicolumn{2}{|c|}{ Insertae sedis } & Rosellinia & 1 \\
\cline { 2 - 5 } & \multicolumn{2}{|c|}{11} & Stegonsporium & 2 \\
\hline
\end{tabular}

Table 1: Taxonomic structure of the biota of ascomycetes of the Malaisary ridge.

The class of Leotiomycetes is represented by 2 orders, 2 families with 8 genera and genus Cylindrosporium with unclear systematic position. The largest genera are Golovinomyces (6 species), Erysiphe (6 species) and Podosphaera (5 species), related to order Erysiphales. Helotiales order has two species of the genus Pseudopeziza from the family Dermateaceae.

The Pezizomycetes class is represented by two species from genera Pseudodichomera and Schwarzmannia with an unclear systematic position.
Genera of the Sordariomycetes class contain 1-2 species, with the exception of 3 species of the genus Strickeria with an unclear systematic position.

There are only 4 species of ascomycetous fungi from 4 genera in the foothill plain of the northern macroslope (Sands of Zhineshkekum) (Table 2). All these species are found both in the foothill plain and in the steppe belt of the Malaisary ridge.

\begin{tabular}{|c|c|c|c|c|c|c|c|}
\hline \multirow{3}{*}{ Options } & \multicolumn{5}{|c|}{ The Main Ridge of the Malaisary } & \multirow{3}{*}{ Arkharly } & \multirow{3}{*}{ Kulanbasy } \\
\hline & \multicolumn{3}{|c|}{ Northern Macroslope } & \multicolumn{2}{|c|}{ Southern Macroslope } & & \\
\hline & $\begin{array}{l}\text { Foothill } \\
\text { Plain }\end{array}$ & $\begin{array}{c}\text { The Steppe } \\
\text { Belt }\end{array}$ & $\begin{array}{c}\text { The shrub } \\
\text { belt }\end{array}$ & $\begin{array}{c}\text { The steppe } \\
\text { belt }\end{array}$ & $\begin{array}{c}\text { The shrub } \\
\text { belt }\end{array}$ & & \\
\hline Number of species & 4 & 35 & 6 & 46 & 10 & 32 & 7 \\
\hline Number of genera & 4 & 23 & 6 & 26 & 10 & 23 & 6 \\
\hline $\begin{array}{l}\text { Ratio of species } \\
\text { and genera }\end{array}$ & 1 & 1.5 & 1 & 1.8 & 1 & 1.4 & 1.2 \\
\hline
\end{tabular}

Table 2: Characteristics of biota of ascomycetes of the Malaisary ridge.

The greatest number of species of ascomycetes is noted in the steppe belt of the Malaisary ridge: on the northern macroslope 35 species from 23 genera, on the southern macroslope 46 species from 26 genera (Table $2)$. A large number of species on the southern slope is registered due to the fact that it is rocky and steep with deep gorges. Therefore, the various ecological conditions are characteristic of the southern macroslope. It is interesting to note that in the steppe belt of the Malaisary ridge only 12 species of ascomycetes are common between the northern and southern macroslopes, and the vast majority of them (8 species) belongs to powdery mildew fungi. The most commonly observed species: Blumeria graminis (DC) Speer,
Erysiphe cruciferarum (Opiz) L Junell, and Erysiphe polygoni DC (Figure 3), Golovinomyces cynoglossi (Wallr) VP Heluta (Figure 4), Leveillula taurica (Lev) G Arnaud (Figure 5) and Neoerysiphe galeopsidis (DC) U Braun (Figure 6). The northern macro slope is characterized by a diversity of representatives of the genera Mycosphaerella and Selenophoma, while the southern macroscope-by representatives of the genus Ramularia.

The shrub belt occupies a small area on the territory of the Malaisary ridge and is characterized by a small number of species of ascomycetous fungi: on the northern macroslope 6 species from 6 genera, on the southern macroslope 10 
species from 10 genera (Table 2). Common to the northern and southern macro slopes are 3 species of ascomycetes.
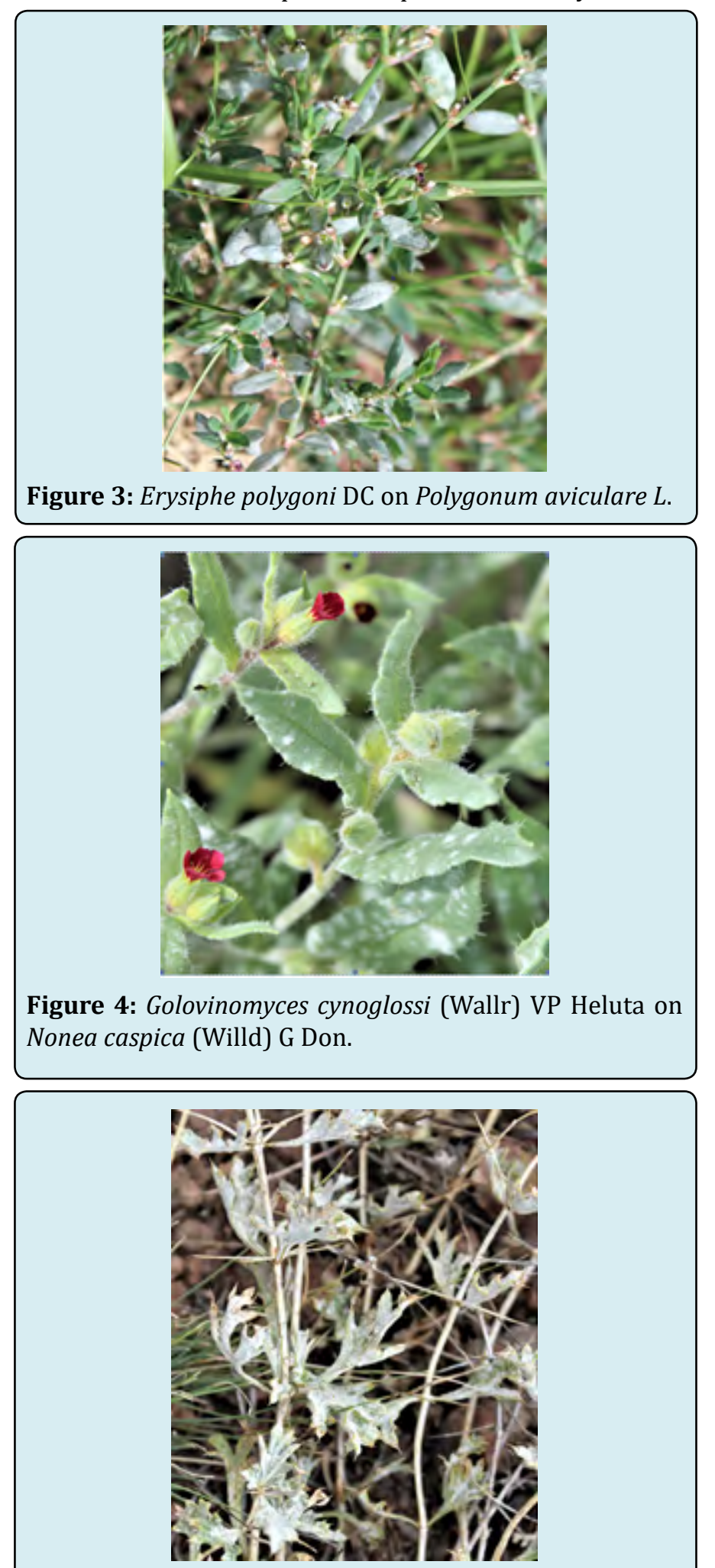

Figure 5: Leveillula taurica (Lév) G Arnaud on Lagochilus platycalyx Schrenk.

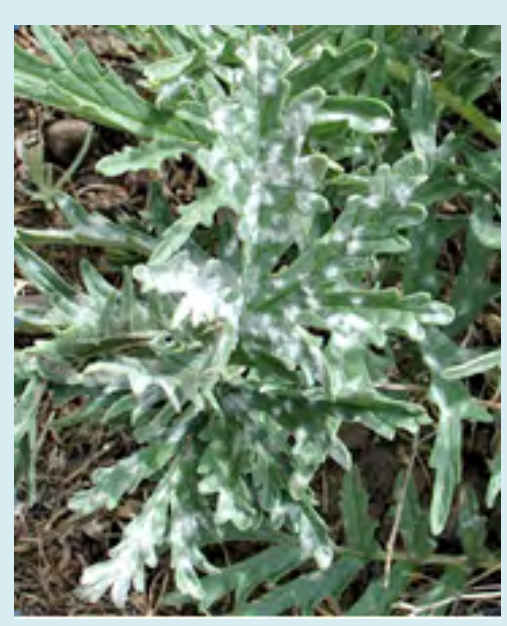

Figure 6: Neoerysiphe galeopsidis (DC) U Braun on Phlomoides iliensis (Regel) Adylov, Kamelin \& Makhm.

In the strongly dissected Arkharly Mountains with various environmental conditions, 32 species of fungi from 23 genera are found, while in the smoothed low mountains of Kulanbasy there are only 7 species from 6 genera (Table 2).

Ascomycetous fungi attack 106 species of vascular plants on the territory of the Malaisary ridge.

\section{Discussion}

The Chulak and Altyn-Emel ranges are the closest to Malaisary. However, the species composition of the mycobiota Altyn-Emel and Chulak totals 56 and 20 species, respectively (Table 3).

Species of 11 genera of ascomycete fungi are found in all three ranges and the number of representatives of the genera Blumeria, Camarosporium, Fumago, Neoerysiphe and Rosellinia is approximately the same. The genera Erysiphe, Golovinomyces, and Pleospora are represented by a large number of species in Malaisary, and the genus Strickeria is represented in Altyn-Emel. Species of 10 genera are common for the mycobiota of the Malaisary and Altyn-Emel ranges, while only 1 genus (Septoria) is found in both Malaisary and Chulak. Species of 24 genera of ascomycetous fungi were found only in Malaisary, 9 genera only in Altyn-Emel. It should be noted that a greater number of species of fungi from the genera Camarosporium, Cytospora and Strickeria, recorded on tree-shrubbery vegetation, are characteristic of the Altyn-Emel ridge (up to $2000 \mathrm{~m}$ above sea level), which is characterized by sufficient humidity. On the other hand, representatives of two mycophilic genera Ampelomyces and Sphaerellopsis were found only in Malaisary. 


\section{Open Access Journal of Mycology \& Mycological Sciences}

\begin{tabular}{|c|c|c|c|}
\hline \multirow{2}{*}{ Genera } & \multicolumn{3}{|c|}{ Number of Species in the } \\
\hline & Malaisary Ridge & Chulak Mountains [19] & Altyn-Emel [20] \\
\hline Alternaria & 2 & - & 2 \\
\hline Ampelomyces & 1 & - & - \\
\hline Blumeria & 1 & 1 & 1 \\
\hline Camarosporium & 2 & 2 & 3 \\
\hline Chaetoplea & - & - & 1 \\
\hline Cladosporium & 3 & - & 1 \\
\hline Claviceps & 1 & - & - \\
\hline Coniochaeta & - & - & 1 \\
\hline Coniothyrium & - & - & 1 \\
\hline Coryneum & 1 & - & - \\
\hline Cucurbitaria & 2 & - & 2 \\
\hline Cylindrosporium & 2 & - & - \\
\hline Cytospora & - & 1 & 7 \\
\hline Diplodia & 1 & - & - \\
\hline Discosphaerina & 1 & - & - \\
\hline Erysiphe & 6 & 1 & 2 \\
\hline Fumago & 1 & 1 & 1 \\
\hline Golovinomyces & 6 & 3 & 1 \\
\hline Graphyllium & 1 & - & - \\
\hline Hendersonia & - & - & 1 \\
\hline Hormiscium & 1 & - & 1 \\
\hline Kabatia & 1 & - & - \\
\hline Leptosphaeria & 1 & - & - \\
\hline Leucostoma & 1 & - & 1 \\
\hline Leveillula & 1 & - & 1 \\
\hline Lophiostoma & 2 & - & 1 \\
\hline Macrosporium & 1 & - & - \\
\hline Microdiplodia & 1 & - & - \\
\hline Mycosphaerella & 7 & - & - \\
\hline Mухоғияicoccum & - & - & 1 \\
\hline Nectria & - & - & 1 \\
\hline Neoerysiphe & 2 & 2 & 1 \\
\hline Ohleria & 1 & - & - \\
\hline Phaeoseptoria & - & - & 1 \\
\hline Phaeosphaeria & 2 & - & - \\
\hline Phoma & 2 & - & 2 \\
\hline Phyllachora & - & - & 1 \\
\hline Phyllactinia & - & - & 1 \\
\hline Placosphaeria & 1 & - & - \\
\hline
\end{tabular}




\section{Open Access Journal of Mycology \& Mycological Sciences}

\begin{tabular}{|c|c|c|c|}
\hline Pleomassaria & 1 & - & 1 \\
\hline Pleospora & 7 & 2 & 1 \\
\hline Podosphaera & 5 & 1 & 5 \\
\hline Polystigma & 1 & - & - \\
\hline Poronia & 1 & - & - \\
\hline Pseudodichomera & 1 & - & - \\
\hline Pseudopeziza & 2 & - & 1 \\
\hline Ramularia & 5 & - & - \\
\hline Rosellinia & 1 & 1 & 3 \\
\hline Schwarzmannia & 1 & - & - \\
\hline Scirrhia & - & - & - \\
\hline Selenophoma & 5 & - & - \\
\hline Septoria & 4 & 1 & - \\
\hline Sphaerellopsis & 1 & - & 6 \\
\hline Stegonsporium & 2 & - & 2 \\
\hline Stemphylium & 2 & - & 56 \\
\hline Strickeria & 3 & 3 & \\
\hline Torula & 2 & 1 & \\
\hline Total & 99 & 20 & \\
\hline
\end{tabular}

Table 3: Number of species of ascomycetes in the Malaisary ridge, Altyn-Emel and Chulak mountains.

\section{Conclusion}

Mycobiota of the Malaisary ridge has 99 species belonging to ascomycetes. The largest genera are Mycosphaerella (7 species), Pleospora (7 species), Golovinomyces (6 species), Erysiphe (6 species), Podosphaera (5 species), and Ramularia (5 species). The most other genera contain 1-2 species. The greatest number of species of ascomycetes is noted in the steppe belt of the Malaisary ridge: on the northern macroslope 35 species from 23 genera, on the southern macroslope 46 species from 26 genera. The northern macro slope is characterized by a diversity of representatives of the genera Mycosphaerella and Selenophoma, while the southern macroscope-by representatives of the genus Ramularia.

\section{Funding}

This work was financed by the Ministry of Education and Science of the Republic of Kazakhstan within the limits of the research program BR05236546 "Implementation by the State Botanical Gardens of the priority scientific and practical tasks of the Global Strategy for Plant Conservation as a Sustainable Biodiversity Maintenance System", 20182020 (Contract №340 from 03.04.2018).

\section{References}

1. Tectonics of Eurasia (1966) The explanatory Notes to the Tectonic Map of Eurasia. Academy of Sciences of the USSR, Geological Institue, Moscow, Russia, pp: 1-487.

2. Akzhygitova NI, Breckle SW, Winkler G (2003) Botanical geography of Kazakhstan and Middle Asia (desert region). Boston-Spectrum, St. Peterburg, Russia, pp: 1-424.

3. (2014) The Red Data Book of Kazakhstan. $2^{\text {nd }}$ (Edn.), In: Baitulin IO, Sitpayeva GT, et al. (Eds.), V. 2. Part 1. LTD "AptPrintXXI", Astana, KZ, pp: 1-452.

4. Poliksenova VD, Khramtsov AK, Piskun SG (2004) Guidelines for the special practicum in the section "Mycology, methods of experimental study of microscopic fungi". BSU, Minsk, Belorussia, pp: 1-36.

5. Vassyagina MP, Kuznetsova MN, Pisareva NF, Schwartzman S (1961) Flora of spore plants in Kazakhstan. Powdery mildew fungi. V. 3. Nauka, AlmaAta, KZ, pp: 1-460. 
6. Byzova ZM, Vasyagina MP (1981) Flora of spore plants of Kazakhstan. Ascomycetous fungi. 1. V. 12. Nauka, AlmaAta, KZ, pp: 1-243.

7. Byzova ZM, Vasyagina MP, Deyeva NG, Kalymbetov BK, Pisareva NF, et al. (1967) Flora of spore plants of Kazakhstan. Imperfect fungi. 1. V. 5. Nauka, Alma-Ata, KZ, pp: 1-340.

8. Byzova ZM, Vasyagina MP, Deyeva NG, Kalymbetov BK, Pisareva NF, et al. (1968) Flora of spore plants of Kazakhstan. Imperfect fungi. 2. V. 5. Nauka, Alma-Ata, KZ, pp: 1-383.

9. Byzova Z, Vasyagina M, Deyeva NG, Kalymbetov BK, Pisareva NF, et al. (1970) Flora of spore plants of Kazakhstan. Imperfect fungi. 3. V. 5. Nauka, Alma-Ata, KZ, pp: 1-558.

10. Schwartzman S, Vasyagina M, Byzova Z, Filimonova N (1973) Flora of spore-bearing plants of Kazakhstan. Vol. 8. Fungi imperfect (Deuteromycetes). 1. Moniliales. Alma-Ata, KZ, pp: 527.

11. Schwartzman S, Vasyagina M, Byzova Z, Filimonova N (1975) Flora of spore plants of Kazakhstan. Imperfect fungi (Deuteromycetes). 2. Moniliales, Alma-Ata, KZ, pp: 1-518.

12. Vassyagina MP, Byzova ZM, Tartenova MA (1987) Flora of spore plants in Kazakhstan. Ascomycetous fungi. 2. V. 12. Nauka, Alma-Ata, KZ, pp: 1-293.
13. Seifert K, Jones MG, Gams W, Kendrick B (2011) The Genera of Hyphomycetes. CBS-KNAW Fungal Biodiversity Series, Utrecht, the Netherlands, pp: 1-997.

14. Braun U, Cook RTA (2012) Taxonomic manual of the Erysiphales (Powdery Mildews). CBS-KNAW Fungal Biodiversity Centre, Utrecht, the Netherlands, pp: 707.

15. Rakhimova YV, Nam GA, Yermekova BD (2014) A brief illustrated guide to powdery mildew fungi in Kazakhstan and border areas. TsRNS Publishing House, Novosibirsk, Russia, pp: 1-129.

16. Kirk PM, Cannon P, Minter D, Stalpers J (2008) Ainsworth and Bisby's dictionary of the fungi, $10^{\text {th }}$ (Edn.), CABI, Wallingford, UK, pp: 1-771.

17. Plantarium, the determinant of plants on-line.

18. Index Fungorum Database.

19. Rakhimova YV, Kyzmetova LA, Yermekova BD (2017) Checklist of rust fungi from Ketmen ridge (southeast of Kazakhstan). Plant Pathology \& Quarantine 7(2): 110135.

20. Rakhimova YV, Nam GA, Yermekova BD, Jetigenova UK, Yessengulova BZh, et al. (2016) To the study of the mycobiota of the national park "Altyn-Emel" and adjacent territories. Proceedings of the state national natural park "Altyn-Emel" 2. Almaty, KZ, pp: 45-62. 